\title{
Opioids and suckling in relation to inhibition of oestradiol-induced LH secretion in postpartum ewes
}

\author{
D. Smart*, I. Singh, R. F. Smith and H. Dobson \\ Department of Veterinary Clinical Science, University of Liverpool, Leahurst, Neston, South Wirral \\ L64 7TE, UK
}

\begin{abstract}
The effects of time postpartum and suckling status on the oestradiol-induced LH surge in ewes and some of the possible mechanisms involved were investigated. Lambs were removed from nonsuckled ewes at parturition (day 0 ) and the ewes hand-milked 12 and $48 \mathrm{~h}$ later to prevent discomfort. Nonsuckled ewes on day 1, 7, 14 or 28, and suckled ewes on day 7 or 28 postpartum were injected i.m. with $50 \mu$ g oestradiol benzoate (hour 0 ). A further eight suckled ewes were given oestradiol on day 1 (as above), and four were also given naloxone ( $1 \mathrm{mg} \mathrm{kg}^{-1} \mathrm{~h}^{-1}$ ) from 10 until $14 \mathrm{~h}$ after administration of oestradiol benzoate. There was no $\mathrm{LH}$ surge in response to oestradiol on day 1 . In nonsuckled ewes the onset of the LH surge was significantly $(P<0.05)$ delayed when oestradiol was administered on day $7(17.4 \pm 1.5 \mathrm{~h}$ ), compared with when it was injected on days 14 and 28 postpartum $(14.4 \pm 1.7$ and $14.0 \pm 1.4 \mathrm{~h}$ ). The $\mathrm{LH}$ surge was also delayed $(P<0.05)$ when oestradiol was administered on day $7(18.0 \pm 2.8 \mathrm{~h})$ in suckled ewes. There was no difference in the duration or amplitude of the LH surge with time postpartum in nonsuckled ewes. Suckling significantly $(P<0.05)$ reduced the amplitude of the LH surge on both day $7(21.0 \pm 2.4$ versus $\left.26.4 \pm 2.3 \mathrm{ng} \mathrm{ml}^{-1}\right)$ and day $28\left(23.6 \pm 3.2\right.$ versus $\left.28.8 \pm 2.9 \mathrm{ng} \mathrm{ml}^{-1}\right)$, but had no effect on the onset or duration of the surge. There was no difference in the timing or the amplitude of the oestradiol peak following the oestradiol benzoate challenge with time postpartum. Naloxone had no effect on the mean LH concentration (control, $2.3 \pm 1.6$; naloxone-treated, $2.2 \pm 1.5 \mathrm{ng} \mathrm{ml}^{-1}$ ) or on the pattern of LH secretion on day 1 . In conclusion, time postpartum influenced the timing of the onset, while suckling reduced the amplitude, of the oestradiol-induced LH surge. The lack of an oestradiol-induced LH surge on day 1 postpartum in the ewe is due to a nonopioidergic mechanism.
\end{abstract}

\section{Introduction}

After parturition, the endocrine mechanisms controlling ovulation are disrupted, leading to postpartum anoestrus in many species, including sheep and cows (Nett, 1987). In dairy cows during this period, the time taken for oestradiol benzoate to elicit an $\mathrm{LH}$ surge decreases as time postpartum increases (Alam and Dobson, 1987). In sheep, the percentage of ewes responding to oestradiol benzoate with an LH surge increases with time postpartum, with no ewes responding before day 3 postpartum (Wright and Findlay, 1977; Wright et al., 1980), although precise parameters of the LH surges were not determined.

Lactation has also been associated with postpartum anoestrus (Peters and Lamming, 1990). In sheep, suckling delays the return to cyclicity in some breeds (Call et al., 1976) but not in others (Moss et al., 1980). Furthermore, this effect of suckling on postpartum anoestrus also varies within a breed, depending upon whether lambing occurred in the spring or in the autumn (Pope et al., 1989). Further studies on the mechanism by which

*Present address and correspondence: Department of Araesthesia, Leicester Royal Infirmary, Leicester LE1 5WW, UK.

Received 28 July 1993. such effects could be mediated revealed that suckling inhibits tonic LH secretion in sheep (Schirar et al., 1990), as in cows (Convey et al., 1982) and rats (Taya and Sasamoto, 1989).

Parturition is both a painful and stressful experience, with associated high peripheral concentrations of opioids, which have been linked to the suppression of gonadotrophin secretion and to postpartum acyclicity (Millan and Herz, 1985; Haynes et al., 1989). Administration of the opioid antagonist naloxone ( $1 \mathrm{mg} \mathrm{kg}{ }^{-1}$ ) increases tonic $\mathrm{LH}$ secretion in postpartum (Malven and Hudgens, 1987) and cyclic (Gregg et al., 1983) ewes. Naloxone also increases tonic LH secretion in cows (Whisnant et al., 1986).

In ewes there is some evidence to suggest a link between opioids and oestradiol positive feedback (Currie and Rawlings, 1987; Knight et al., 1990). Such a link has been established in rats, in which naloxone increases the LH surge response to oestradiol (Gabriel et al., 1983).

The aim of the present study was to investigate whether time postpartum or suckling or both influences the parameters of the oestradiol-induced LH surge in ewes, and what role opioids play in the inability of oestradiol to induce an LH surge in the early postpartum period.

Downtoaded from Bioscientifica.com at 04/26/2023 07:39:29AM 


\section{Materials and Methods}

\section{Animals and collection of blood samples}

Mature, spring-lambing Welsh Mountain ewes, of approximately $35 \mathrm{~kg}$ body mass, were housed 2 weeks before parturition in the same room with natural lighting and ambient temperature. After lambing, the ewes were kept in pairs in straw-bedded pens with water and hay freely available.

An indwelling jugular venous catheter was inserted under local anaesthesia ( $2 \mathrm{ml}$ Lignocaine $0.5 \%$, Intervet; Crewe) the day before each experiment, and patency was maintained by filling with heparinized saline $\left(50 \mathrm{iu} \mathrm{ml}^{-1}\right)$. Blood samples $(7 \mathrm{ml})$ were taken into heparinized syringes $\left(50 \mathrm{iu} \mathrm{ml}{ }^{-1}\right)$, immediately centrifuged at $1000 \mathrm{~g}$ for $10 \mathrm{~min}$ and the plasma was stored at $-20^{\circ} \mathrm{C}$.

\section{Experimental design}

At parturition (day 0 ) the ewes were randomly divided into two groups: suckled (one lamb per ewe) and nonsuckled. Lambs were removed from the ewes in the nonsuckling group on day 0 , and the ewes hand-milked twice only, 12 and $48 \mathrm{~h}$ after birth, to prevent discomfort.

The $\mathrm{LH}$ response to oestradiol was examined in different groups of nonsuckled ewes on days $1(n=5), 7(n=7), 14$ $(n=5)$ or $28(n=5)$, and in suckled ewes on day $7(n=7)$ or 28 $(n=8)$. On each occasion the ewes were given $50 \mu \mathrm{g}$ oestradiol benzoate in $2 \mathrm{ml}$ arachis oil i.m. (hour 0), and blood samples were collected every $2 \mathrm{~h}$ from $8 \mathrm{~h}$ until $24 \mathrm{~h}$ after oestradiol benzoate injection.

The effect of naloxone on the $\mathrm{LH}$ response to oestradiol on day 1 postpartum was examined in an additional eight suckled ewes given $50 \mu \mathrm{g}$ oestradiol benzoate, as above (hour 0 ). Half of the ewes $(n=4)$ were also given $1 \mathrm{mg}$ naloxone $\mathrm{kg}^{-1}$ (Sigma, Poole) in $2 \mathrm{ml} 0.9 \%$ saline via the catheter once per hour from $10 \mathrm{~h}$ until $14 \mathrm{~h}$ after oestradiol benzoate injection, while the other four ewes received $2 \mathrm{ml}$ saline alone. This dose schedule has previously been used in sheep to modify LH secretion (Gregg et al., 1983). Blood samples were collected from all ewes at $8 \mathrm{~h}, 9 \mathrm{~h}$ and then every $15 \mathrm{~min}$ until $15 \mathrm{~h}$, followed by every $2 \mathrm{~h}$ until $23 \mathrm{~h}$ after oestradiol benzoate injection.

\section{Hormone analysis}

Plasma samples were analysed for oestradiol by a radioimmunoassay characterized and verified by Dobson and Dean (1974). All samples were measured in one assay, with an intra-assay coefficient of variation of $9.9 \%$. The minimum detectable quantity was $1.5 \mathrm{pg} \mathrm{ml}^{-1}$.

Plasma samples were analysed for LH by a radioimmunoassay characterized and verified by Dobson and Ward (1977). In the present study, a specific ovine LH antiserum (Cunningham LH 07/08) and iodinated purified ovine LH (LER 1056 C2) (both donated by F. Cunningham, Reading) were used with $0.1 \mathrm{ml}$ plasma samples, and results were expressed as ng equivalents of NIH-LH-S2I ml ${ }^{-1}$ plasma. Contemporary intra- and interassay coefficients of variation were $9.7 \%$ and
$10.4 \%$, respectively. The minimum detectable quantity was $0.5 \mathrm{ng} \mathrm{ml}^{-1}$.

\section{Statistical analysis}

Results are mean values $\pm \mathrm{SD}$. An LH surge was defined as two or more consecutive samples containing $>10 \mathrm{ng} \mathrm{LH}$ $\mathrm{ml}^{-1}$. The onset of the surge was defined as the time of the first sample with $\mathrm{LH}>10 \mathrm{ng} \mathrm{ml}^{-1}$. Duration of the $\mathrm{LH}$ surge was defined as the time $\mathrm{LH}$ was $>10 \mathrm{ng} \mathrm{ml}^{-1}$. Amplitudes were defined as peak height. LH pulsatility was defined using the criteria of Webb et al. (1985). Briefly, an LH pulse was considered to have occurred if the lower $95 \%$ confidence limit of the peak (maximum turning point) was greater in value than twice the upper $95 \%$ confidence limit of the previous nadir (minimum turning point). Data were compared where appropriate by Student's $t$ test, following ANOVA where $p<0.05$.

\section{Results}

There was no difference in either the timing ( $11 \pm 2.3,13 \pm 0$ and $12 \pm 2 \mathrm{~h}$, respectively) or amplitude $(63.5 \pm 11.3$, $64.8 \pm 3.8$ and $63.7 \pm 12.6 \mathrm{pg} \mathrm{ml}^{-1}$, respectively) of the oestradiol peak following i.m. injection of oestradiol benzoate between days 1,7 and 14 postpartum in nonsuckled ewes.

There was no LH surge in response to oestradiol on day 1 in any ewe. However, on days 7, 14 and 28 all ewes responded to the oestradiol challenge with an LH surge.

In nonsuckled ewes the onset of the oestradiol-induced $\mathrm{LH}$ surge was significantly $(P<0.05)$ delayed when oestradiol was injected on day 7 , compared with results from ewes injected on days 14 and 28 (Table 1). However, there was no difference in LH surge duration or amplitude with time postpartum (Table 1 ).

In suckled ewes injected with oestradiol on day 7 , the onset of the oestradiol-induced LH surge was significantly $(P<0.05)$ delayed compared with results from ewes injected on day 28 and the surge duration was significantly $(P<0.01)$ reduced, but there was no difference in surge amplitude (Table 1 ).

In suckled ewes compared with nonsuckled ewes, the amplitude of the oestradiol-induced LH surge was significantly $(P<0.05)$ lower on both day 7 and day 28 . However, suckling had no effect on the onset or duration of the LH surge on either day (Table 1).

On day 1 postpartum in the suckled ewes there was no $\mathrm{LH}$ surge in response to oestradiol in either the control or the naloxone-treated groups. Naloxone had no effect on the overall mean LH concentration (control, $2.3 \pm 1.6$; naloxonetreated, $2.2 \pm 1.5 \mathrm{ng} \mathrm{ml}^{-\mathrm{I}}$ ), or on the overall $\mathrm{LH}$ profiles (Fig. 1). The LH pulse frequency over the period $10-15 \mathrm{~h}$ after oestradiol benzoate treatment was $0.9 \pm 0.1$ pulses $h^{-1}$ for both control and naloxone-treated ewes.

\section{Discussion}

The lack of an oestradiol-induced LH surge on day 1 postpartum in the study reported here is in agreement with the findings in suckled ewes on day 3 postpartum (Wright and Findlay, 1977) Downloaded from Bioscientifica.com at 04/26/2023 07:39:29AM 
Table 1. Mean ( \pm SD) characteristics of the LH surge in suckled (S) and non-suckled (NS) ewes pretreated with $50 \mu \mathrm{g}$ oestradiol benzoate i.m. (hour 0 )

\begin{tabular}{lccc}
\hline Ewes & Onset time $(\mathrm{h})$ & Duration $(\mathrm{h})$ & Amplitude (ng ml $\left.{ }^{-1}\right)$ \\
\hline $\begin{array}{l}\mathrm{NS} \text {, day } 7 \\
(n=7)\end{array}$ & $17.4 \pm 1.5^{\mathrm{a}}$ & $6.8 \pm 1.0^{\mathrm{a}, \mathrm{b}}$ & $26.4 \pm 2.3^{\mathrm{a}}$ \\
$\begin{array}{l}\mathrm{NS} \text {, day } 14 \\
(n=5)\end{array}$ & $14.4 \pm 1.7^{\mathrm{b}}$ & $7.6 \pm 0.9^{\mathrm{a}}$ & $27.3 \pm 2.6^{\mathrm{a}}$ \\
$\begin{array}{l}\mathrm{NS} \text {, day } 28 \\
(n=5)\end{array}$ & $14.0 \pm 1.4^{\mathrm{b}}$ & $7.6 \pm 0.9^{\mathrm{a}}$ & $28.8 \pm 2.9^{\mathrm{a}}$ \\
$\begin{array}{l}\mathrm{S} \text { day } 7 \\
(n=7)\end{array}$ & $18.0 \pm 2.8^{\mathrm{a}}$ & $6.0 \pm 0.0^{\mathrm{b}}$ & $21.0 \pm 2.4^{\mathrm{b}}$ \\
$\mathrm{S}, \begin{array}{l}\text { day } 28 \\
(n=8)\end{array}$ & $14.5 \pm 1.4^{\mathrm{b}}$ & $7.8 \pm 0.7^{\mathrm{a}}$ & $23.6 \pm 3.2^{\mathrm{b}}$ \\
\hline
\end{tabular}

Within a column, groups without a common superscript are significantly different $(P<0.05)$.

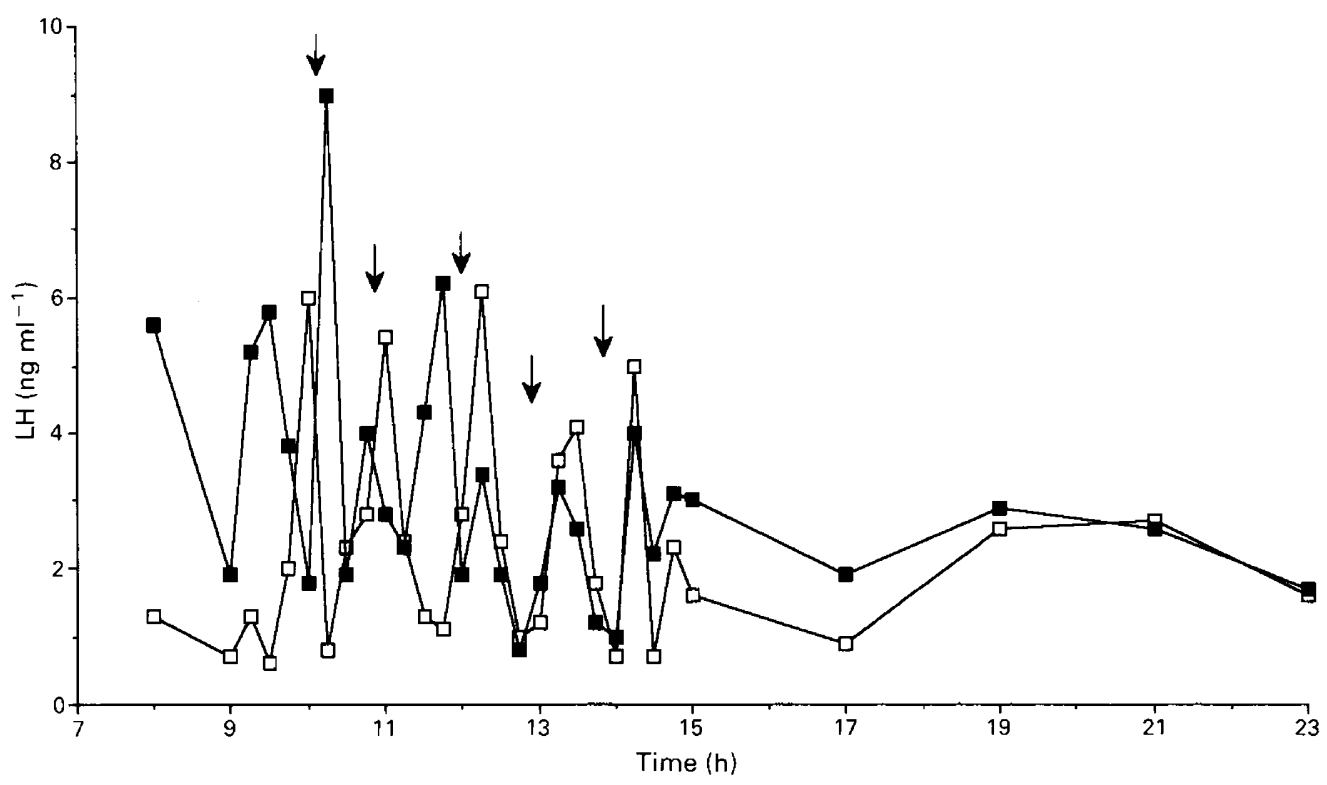

Fig. 1. A typical LH response to the administration of $50 \mu \mathrm{g}$ oestradiol benzoate i.m. (hour 0 ) ( $\square$ ) with and ( $\square$ ) without naloxone treatment ( $1 \mathrm{mg} \mathrm{kg}{ }^{-1} \mathrm{~h}^{-1}$ from 10 to $14 \mathrm{~h}$ after oestradiol benzoate treatment) in day I postpartum ewes (arrows indicate time of naloxone or saline injections).

and in day 1 postpartum cows (Alam and Dobson, 1987). On days 1-3 postpartum in ewes not pretreated with oestradiol, there were fewer $\mathrm{GnRH}$ and oestrogen receptors in the pituitary (Crowder et al., 1982; Clarke et al., 1984), and a reduced $\mathrm{GnRH}$ pulsatility (Wise, 1990). Thus, oestradiol positive feedback would be expected to be impaired at both hypothalamic and pituitary levels. However, the LH pulsatility detected in oestradiol-pretreated ewes in the current investigation was much greater than that reported for day 3 postpartum ewes, which had not been given oestradiol (Wise, 1990). Indeed, the pulsatility of LH in the present study was similar to that found in ewes in the late follicular phase (Domanski et al., 1989), suggesting that oestradiol positive feedback was occurring on day 1 , but that some mechanism was preventing the triggering of the LH surge. This must be a nonopioidergic mechanism because, in the current investi- gation, naloxone could not overcome this inhibition of the LH surge on day 1 . The failure of oestradiol to induce an $\mathrm{LH}$ surge in day 1 postpartum ewes could have been due to a lack of $\mathrm{LH}$, particularly in the readily releasable pool, since total $\mathrm{LH}$ stores have been found to be depleted in ewes on days $1-3$ postpartum (Wise et al., 1986).

In the present study all of the ewes from day 7 postpartum onwards, in both the suckled and nonsuckled groups, displayed an $\mathrm{LH}$ surge in response to oestradiol. This percentage (100\%) was much greater than that $(50 \%)$ reported for Merino ewes (Wright et al., 1980). This discrepancy was probably due to the lower dose $\left(0.7 \mu \mathrm{g} \mathrm{kg}^{-1}\right.$ compared with $\left.1.42 \mu \mathrm{g} \mathrm{kg}{ }^{-1}\right)$ of oestradiol benzoate used in the previous study. Other studies have shown a negative correlation between the dose of oestradiol and the ease with which the ensuing LH response was disrupted (Yuthasastrakosol et al., 1974). 
The onset of the oestradiol-induced LH surge was delayed on day 7 compared with days 14 and 28 in both the suckling and nonsuckling ewes. A similar delay has been reported for dairy cows (Alam and Dobson, 1987).

Both the hypothalamic and pituitary actions of oestradiol are necessary to induce an LH surge (Kaynard et al., 1988). However, in early postpartum ewes $\mathrm{GnRH}$ pulsatility is reduced (Wise, 1990), as is the number of hypothalamic oestradiol receptors (Wise et al., 1988). In addition, pituitary responsiveness to GnRH is suppressed in the early (Crowder et al., 1982) but not the late (Wright et al., 1983) postpartum ewe. Furthermore, there are fewer oestradiol receptors in the pituitary in the early postpartum ewe (Clarke et al., 1984). Oestradiol positive feedback would therefore be impaired at both the hypothalamic and pituitary levels, and this could lead to the delay of the oestradiol-induced LH surge in the day 7 postpartum ewe. This could also explain the shortened duration of the LH surge in the suckled ewe on day 7 postpartum.

The amplitude of the oestradiol-induced LH surge did not vary with time postpartum in the present study, confirming previous findings for ewes (Restall et al., 1977).

There was no difference in either the timing or the amplitude of the oestradiol peak with day postpartum in nonsuckling ewes, a finding previously reported for endogenous oestradiol secretion in suckling ewes (Mandiki et al., 1990). Altered oestradiol metabolism cannot therefore be responsible for the delayed oestradiol-induced LH surge on day 7 .

Suckling per se had no effect on the onset or duration of the oestradiol-induced LH surge. However, suckling did inhibit the amplitude of the oestradiol-induced $\mathrm{LH}$ surge to a similar degree in both early and late stage postpartum ewes. This reduction could not be due to an altered rate of oestradiol metabolism, as this was not affected by suckling in sheep (Mandiki et al., 1990). Another possible mechanism is the reduction of the pituitary responsiveness to $\mathrm{GnRH}$. However, although suckling has been reported to inhibit GnRH-induced LH secretion in sheep (Newton et al., 1988), this has been disputed (Moss et al., 1980). There are no changes in numbers of GnRH receptors in suckled ewes (Peters and Lamming, 1990). In cows there is also no change in GnRH-induced LH secretion or number of GnRH receptors with suckling (Parfet et al., 1986). Alternatively, suckling could inhibit LH secretion by suppressing $\mathrm{GnRH}$ pulsatility. Opioids modulate $\mathrm{GnRH}$ secretion (Haynes $e$ al., 1989) and have been implicated in the inhibition of LH secretion by suckling (Gregg et al., 1983).

In conclusion, the onset of the oestradiol-induced LH surge was delayed in the early (day 7), but not in the late (day 14 or more), postpartum ewe. Furthermore, suckling reduced the amplitude of the oestradiol-induced LH surge in both early and late postpartum ewes. In addition, the lack of an LH surge response to oestradiol on day 1 postpartum is due to a nonopioidergic mechanism.

The authors thank H. Pursell, T. Roscoe and J. Smith for technical assistance, and the Whitley Animal Protection Trust for financial support.

\section{References}

Alam MGS and Dobson H (1987) Pituitary responses to a challenge test of $\mathrm{GnRH}$ and oestradiol benzoate in postpartum and regularly cyclic dairy cows Animal Reproduction Science 14 I-9
Call JW, Foote WC, Eckre CD and Hulet CV (1976) Postpartum uterine and ovarian changes and estrous behaviour from lactation effects in normal and hormone treated ewes Theriogenology 6 495-501

Clarke IJ, Wright PJ, Chamley WA and Burman K (1984) Differences in the reproductive endocrine status of ewes in the early post-partum period and during seasonal anoestrus Journal of Reproduction and Fertility 70 591-597

Convey EM, Walters DL and Short RE (1982) Pituitary function in suckled and weaned cows postpartum. In Factors Influencing Fertility in the Postpartum Cow pp 229-233 Ed. H Karg and E Schallenberger. Martinus Nijhoff, Dordrecht

Crowder ME, Gilles PA, Tamanini C, Moss GE and Nett TM (1982) Pituitary content of gonadotropins and $\mathrm{GnRH}$ receptors in pregnant, postpartum and steroid-treated ovariectomized ewes Journal of Animal Science $\mathbf{5 4}$ 1235-1242

Currie WD and Rawlings NC (1987) Naloxone enhances LH but not FSH release during various phases of the estrous cycle in the ewe Life Sciences $\mathbf{4 1}$ 1207-1214

Dobson H and Dean P (1974) Radioimmunoassay of oestrone, oestradiol 17 alpha and beta in bovine plasma during the oestrous cycle and last stage of pregnancy Journal of Endocrinology 61 479-486

Dobson H and Ward WR (1977) Alterations in plasma gonadotrophin patterns caused by sodium pentobarbitone in ewes at oestrus and in anoestrous ewes after infusion of oestradiol Journal of Endocrinology 75 109-118

Domanski E, Przekop F, Chomicka L and Ostrowska A (1989) Effects of stress on the course of the oestrous cycle and the release of luteinizing hormone; the role of endorphin in these processes Acta Physiologica, Polonica 40 64-73

Gabriel SM, Simpkins JW and Kalra SP (1983) Modulation of endogenous opioid influence on luteinizing hormone secretion by progesterone and estrogen Endocrinology 113 1806-1811

Gregg DW, Moss GE, Hudgens RE and Malven PV (1983) Endogenous opioid modulation of luteinizing hormone and prolactin secretion in post-partum ewes and dairy cows Journal of Animal Science 63 838-847

Haynes NB, Lamming GE, Yang KP, Brooks AN and Finnie AD (1989) Endogenous opioid peptides and farm animal reproduction Oxford Reviews in Reproductive Biology 11 111-145

Kaynard AH, Malpaux B, Robinson JE, Wayne NL and Karsch FJ (1988) Importance of pituitary and neural actions of estradiol in induction of the luteinizing hormone surge in the ewe Neuroendocrinology 48 296-303

Knight PG, Stansfield SC and Cunningham FJ (1990) Attenuation by an opioid agonist of the oestradiol-induced LH surge in anoestrous ewes and its reversal by naloxone Domestic Animal Endocrinology 7 165-172

Malven PV and Hudgens RE (1987) Naloxone reversible inhibition of LH in postpartum ewes: effects of suckling and season Journal of Animal Science 65 196-202

Mandiki S, Bister J and Paquay R (1990) Effects of suckling mode on endocrine control of reproductive activity resumption in Texel ewes lambing in July or November Theriogenology 33 397-413

Millan RL and Herz A (1985) The endocrinology of the opioids International Review of Neurobiology 26 1-83

Moss GE, Adams TE, Niswender GD and Nett TM (1980) Effects of parturition and suckling on concentrations of pituitary gonadotropins, hypothalamic $\mathrm{GnRH}$ and pituitary responsiveness to GnRH in ewes Journal of Animal Science 50 496-501

Nett TM (1987) Function of the hypothalamic-hypophysial axis during the post-partum period in ewes and cows Joumal of Reproduction and Fertility Supplement 34 201-213

Newton GR, Schillo KK and Edgerton LA (1988) Effects of weaning and naloxone on luteinizing hormone secretion in postpartum ewes Biology of Reproduction 39 532-535

Parfet JR, Marvin CA, Allrich RD, Diekman MA and Moss GE (1986) Anterior pituitary concentrations of gonadotropins, GnRH receptors and ovarian characteristics following early weaning in beef cows Journal of Animal Science $62717-722$

Peters AR and Lamming GE (1990) Lactational anoestrus in farm animals Oxford Review of Reproductive Biology 12 245-288

Pope WF, McClure KE, Hogue DE and Day ML (1989) Effect of season and lactation on postpartum fertility of Polypay, Dorset, St Croix and Targhee ewes Journal of Animal Science 67 1167-1174

Restall BJ, Kearins RD and Starr BG (1977) Studies of pituitary function in lactating ewes Journal of Reproduction and Fertility 49 291-296

Schirar A, Cognie Y., Loulaut F, Poulin N, Meusnier C, Levasseur MC and Martinet $\mathrm{J}$ (1990) Resumption of gonadotrophin release during the post-partum Downloaded from Bioscientifica.com at 04/26/2023 07:39:29AM 
period in suckling and non-suckling ewes Journal of Reproduction and Fertility 88 593-604

Taya K and Sasamoto S (1989) Inhibitory effects of corticotropin-releasing factor and beta-endorphin on LH and FSH secretion in the lactating rat Journal of Endocrinology 120 509-515

Webb R, Baxter G, Preece RD, Land RB and Springbett AJ (1985) Control of gonadotrophin release in Scottish Blackface and Finnish Landrace ewes during seasonal anoestrus Joumal of Reproduction and Fertility 73 369-378

Whisnant CS, Kiser TE, Thompson FN and Barb C (1986) Effect of naloxone on serum $\mathrm{LH}$, cortisol and prolactin concentrations in anestrous beef cows Journal of Animal Science 62 1340-1345

Wise ME (1990) Gonadotropin releasing hormone secretion during the postpartum anoestrus period of the ewe Biology of Reproduction 43 719-725

Wise ME, Sawyer HR and Nett TM (1986) Functional changes in luteinizing hormone secreting cells from pre- and post-partum ewes American Joumal of Physiology 250 E282-E287
Wise ME, Glass JD and Nett TM (1988) Changes in the concentration of hypothalamic and hypophyseal receptors for estradiol in pregnant and postpartum ewes Journal of Animal Science 62 1021-1028

Wright PJ and Findlay JK (1977) LH release due to LHRH or oestradiol-17 $\beta$ in post-partum ewes Theriogenology 8191

Wright PJ, Geytenbeek PE, Clarke IJ and Findlay JK (1980) Pituitary responsiveness to LHRH, the occurrence of oestradiol-17 $\beta$ induced $\mathrm{LH}$ positive feedback and the resumption of oestrous cycles in ewes post-partum Journal of Reproduction and Fertility 60 171-176

Wright PJ, Geytenbeek PE, Clarke IJ and Findlay JK (1983) LH release and luteal function in post-partum acyclic ewes after the pulsatile administration of LHRH Journal of Reproduction and Fertility $67257-262$

Yuthasastrakosol P, Howland BE, Simaraks S and Palmer WM (1974) Estrogeninduced $\mathrm{LH}$ release in progesterone-treated ovariectomized ewes Canadian Journal of Animal Science 54 565-572 